\title{
Are the BRIC countries overtaking intermediate countries in the race for international R\&D? The case of Spain.
}

\author{
Paloma Miravitlles $^{1}$; Fariza Achcaoucaou ${ }^{1 *}$; Ana Núñez-Carballosa ${ }^{1}$; Laura Guitart- \\ Tarrés $^{1}$; Claudio Cruz-Cazares ${ }^{1}$ \\ ${ }^{1}$ Department of Business, University of Barcelona, Barcelona, Spain
}

* Corresponding author.

Fariza Achcaoucaou

University of Barcelona, Faculty of Economy and Business Administration, Department of Business, Av. Diagonal 690, 08034 Barcelona, Spain. E-mail addresses:

farizaa@ub.edu

\section{Short biographical notes}

Paloma Miravitlles is associate professor at the UB. Her main research interest is the field of international business; she focuses in particular on the strategies of multinationals and foreign subsidiaries and internationalization of innovation.

Fariza Achcaoucaou is assistant professor at the UB. Her main research interest is the study of international business and innovation, notably the transfer of knowledge within multinationals and embeddedness.

Ana Núñez-Carballosa is associate professor at the UB. Her main research interest is the study of the strategic behaviour of foreign multinationals.

Laura Guitart-Tarrés is associate professor at the UB. Her main research interest is the location factors of foreign branches established in Spain.

Claudio Cruz-Cázares is a visiting professor at the UB. His research interests are in the field of innovation strategies and open innovation.

Acknowledgements: This study was made possible thanks to the collaboration of the Fundación I+E and funding from the Fundación Española para la Ciencia y la Tecnología, FECYT. 


\begin{abstract}
The emergence of the BRICs as international locations for FDI in R\&D is a sign that multinationals are relocating their technological activities to new territories. This trend may weaken the supremacy of the developed countries until now considered leaders in innovation, and may mean the loss of the competitive advantages enjoyed by the countries considered intermediate innovators. This paper examines the situation of Spain as a typical intermediate economy and compares it to its main competitors among the BRICs. Based on eight case studies of subsidiaries with R\&D centres in Spain, we conclude that the policies adopted by certain emerging economies to develop their national innovation systems are proving effective and that these countries now pose a threat to intermediate economies. However, the BRICs still lag behind in terms of the security of their institutional framework; this situation leaves intermediate countries in an advantageous position.
\end{abstract}

Keywords: R\&D; multinationals; international location factors; innovation.

\title{
1. Introduction
}

In the aftermath of the 2007-08 financial crisis, countries with emerging economies began to establish themselves on the international scene. As the world economy embarked on the path towards recovery in the 2010s, these countries intensified their international presence. Proof of this is their increasing involvement as recipients of foreign direct investment (FDI). In 2015, developing-economy FDI inflows reached record levels accounting for 55 per cent of the global level (UNCTAD 2015).

The reasons that have traditionally led multinational corporations (MNCs) to locate activities in emerging countries are access to resources at competitive costs and entry to new markets with high growth potential (Dunning 1980). Most of the FDI received by these countries is for relatively unsophisticated activities: for instance, the manufacture of components and products and their commercialization in different geographical markets. However, it is clear that some emerging countries such as the 
BRICs (Brazil, India, China and Russia) are rapidly catching up with the world's leading economies in terms of high technology production and technological capabilities (Buckley and Hashai 2014). This technological change does not occur spontaneously; in order to win added-value inward FDI to boost the technological catch-up, emerging countries are increasing their capital investment and expenditure on human capital and R\&D and related innovation activities, coupled with appropriate incentives, institutions and policies (Filipetti and Peyrarche 2011). In this new scenario of global technological convergence, MNCs are relocating some of their R\&D activity from developed countries to emerging economies with greater competitive advantages. As a result, the gap between the more technologically advanced countries and the emerging economies is gradually narrowing. Virtually unthinkable just a few years ago, this clear change of trend seems to be intensifying and poses new challenges for intermediate countries such as Greece, Italy, Ireland, Portugal and Spain. These ‘intermediate countries’ are defined as developed countries with an innovation performance below the average, which are not perceived as technological leaders in their field, but which cannot compete on the basis of low costs alone (Miravitlles et al. 2013). This is particularly the case of Spain, a country that is "stuck in the middle" between the innovation leaders and the emerging economies that are constantly catching up. According to the Global Innovation Index (GII 2015) Spain is in a better position than the BRICs, but lags far behind leading countries (Switzerland, the UK, Sweden, the Netherlands, and the US). Specifically, out of 141 countries, Spain ranks $27^{\text {th }}$, closely followed by China in $29^{\text {th }}$ place; of the other BRICs, Russia comes $48^{\text {th }}$, Brazil $70^{\text {th }}$ and then at some distance India, in $81^{\text {st }}$ position.

In this new situation, it would be useful to find out exactly where the intermediate countries stand in the international competition to attract and retain MNCs' 
R\&D activities. For these economies, it is no longer simply a question of competing with countries traditionally more advanced in terms of innovation; now, they are under threat from the emerging countries that are steadily climbing the table. Taking Spain as a paradigm of an intermediate country, this paper analyses the importance of the different factors in MNCs' decision-making regarding the location of R\&D activities, and also compares the competitive advantages of intermediate countries with those of newly competing countries such as the BRICs. By selecting several elements from different theoretical perspectives, we develop a compound model for exploring the factors that shape the international location of R\&D. Based on the framework constructed, we propose policy recommendations for intermediate countries in order to strengthen their technology supply and to withstand the threat posed by emerging economies.

The paper is structured as follows. First, we present a literature review of R\&D location factors from three different theoretical perspectives. In section 3 we describe the qualitative methodology used. Section 4 presents Spain's strengths and weaknesses for attracting foreign $R \& D$ in the face of competition from emerging economies. Finally, section 5 concludes and proposes some policy recommendations.

\section{Literature on factors affecting international $R \& D$ location}

The importance of location-specific factors for attracting FDI in R\&D is well established in the literature. However, understanding the location characteristics on which MNCs base their FDI decisions is more important today than ever before, primarily because of the rise of the emerging markets (Chidlow et al. 2015). In order to explore this phenomenon, we build a conceptual framework that examines the environmental factors that determine a country's ability to attract investment using three different theoretical perspectives - internalization theory, the resource-based view, and 
the cultural-institutional perspective.

\subsection{The internalization theory perspective}

Until the 1990s, the parent company was considered the main source of competitive advantage for an MNC (Dunning 1980). Internalization theory (Buckley and Casson 1976) holds that MNCs locate their R\&D activity abroad in order to make it easier to transfer technology from the parent company to the subsidiary and to exploit their competitive advantages in another country. In this process, innovation is internationalized in order to provide technical support to production units located abroad and to adapt standardized products to local requirements and tastes (i.e., marketseeking motivations). The tendency to internationalize innovation for exploiting competitive advantages increases in line with the attractiveness of the market in the destination country (Cantwell and Mudambi 2005; Kuemmerle 1999). Voelker and Stead (1999) offered evidence of R\&D laboratories located away from headquarters reducing internal transaction costs only when distant markets attain a critical size. Hence, aspects such as market size, dynamism and competition (de Woskin 2008) are fundamental factors for attracting R\&D. Moreover, since MNCs locate their R\&D activities near production subsidiaries in order to adapt to local markets, the availability of logistics infrastructures and qualified suppliers also plays an indirect but complementary role (Demirbag and Glaister 2010). For Sachwald (2008), the increasingly frequent location of development activities (and, to a lesser extent, research activities) in emerging economies is due to the geographical distribution of the centres of production, which in these countries has intensified due to the increasing attractiveness of their markets after rapid economic growth. 


\subsection{The resource-based view}

A complementary perspective is that in the mid-1990s MNCs converted their foreign subsidiaries into important sources of innovation for the entire corporation (Cantwell and Mudambi 2005) as they became aware of the opportunities of learning from diverse specific bodies of local knowledge (Kuemmerle 1999). Motivated mainly by assetseeking, they were sensitive to technological supply factors, which enable MNCs to increase the value of their resources and capabilities (Prahalad and Hamel 1990). This new reality conforms to the resource-based view, since MNCs that are attracted by technological supply factors see internationalization as a way of creating value in order to achieve new competitive advantages (Prahalad and Hamel 1990).

The tendency to internationalize R\&D following criteria involving supply grows stronger when the foreign country increases the resources it commits to $R \& D$ (Kuemmerle 1999). Therefore, the location of R\&D centres abroad depends on the ease of access to top-level qualified personnel, which in turn depends on the quality of the educational infrastructures (Demirbag and Glaister 2010) and the command of foreign languages (Dachs et al. 2012). Labour costs (Demirbag and Glaister 2010) and staff mobility (Siedschlag et al. 2009) are among the other factors considered. In the case of $\mathrm{R} \& \mathrm{D}$, other studies also endorse the idea that MNCs tend to prioritize the availability of scientific manpower over cost reduction (Thursby and Thursby 2006).

Likewise, MNCs are attributing a growing importance to the dynamism of the $R \& D$ infrastructures, such as the existence of cutting-edge scientific centres and institutions, access to clusters and spillover effects, and the proximity between the business and scientific worlds (Demirbag and Glaister 2010; Guimón 2009). R\&D infrastructures comprise a set of factors and agents which favour the generation, exploitation, and diffusion of knowledge (Evangelista et al. 2015). Hence, the potential 
for establishing deeply embedded links with other institutions such as universities, research centres and other firms contributes to a country's attractiveness for locating foreign subsidiaries (Achcaoucaou et al. 2014).

Public institutions also play a major role in the area of innovation. With their overriding priorities in questions of R\&D policy and funding (Guimón 2009), public institutions act as creators of the attractive environment for the location of FDI in R\&D (Doh et al. 2005) and, therefore, as promoters of a country's technology base. Well aware of this, for over a decade now governments in emerging countries have been introducing science and technology policy measures aimed at developing their own technological capabilities in order to attract foreign $R \& D$ (see the European Commission's ERAWATCH Annual Country Reports 2012).

\subsection{The cultural-institutional perspective}

During the 2010s, as MNCs have increasingly located their R\&D labs in far-off, less developed countries, cultural and institutional distance (or proximity) have also emerged as factors which may act as fundamental barriers (or enablers) in decisions on R\&D investment (Castellani et al. 2013). The idea underpinning the culturalinstitutional perspective (Kostova and Zaheer 1999) is that an MNC that seeks to be a legitimate agent in the local environment will have to adjust its actions, rules, beliefs and practices to those of the host country.

In this respect, political and economic risks represent a highly important dimension of the institutional environment because MNCs have to deal with a new political system and adapt to the new regulations in the host country (Demirbag and Glaister 2010). The weakness of government institutions - reflected by discretionary regulatory powers, corruption, high levels of bureaucracy and a judicial system that fails to provide effective protection of intellectual property, along with legislation and 
attitudes that are not sufficiently open to FDI - not only harm a country's image abroad (see The Global Competitiveness Report by the World Economic Forum, 2015), but may act as a barrier to FDI if they differ notably from the MNC's country of origin (Castellani et al. 2013). As a result, MNCs not only prefer more stable macroeconomic and political-social environments, but also opt for environments with systems that are closer to those in their home countries; this familiarity reduces any perceived uncertainty and considerably increases their chances of success (Flores and Aguilera 2007).

Still with regard to the cultural-institutional perspective, the location of $R \& D$ also depends on the cultural and geographical distance between the host country and the MNC's country of origin (Castellani et al. 2013). Similar working and business practices, low barriers in personal interrelationships and spatial proximity help to foster communication and mutual understanding between the parties involved. In this regard, emerging economies are in a worse position to compete for foreign $\mathrm{R} \& \mathrm{D}$, not only because of geographical distance, but also (and to a significant degree) because of the cultural-institutional distance.

Therefore, the cultural-institutional aspect complements the internalization theory and the resource-based view, insofar as institutions shape the environment in which the market demand and technological supply factors arise. We contend that these three perspectives serve as complementary, partial explanations, which together are able to provide a rich account of the complexity of foreign $R \& D$ location choices (see figure $1)$. 
Figure 1. Environmental factors in the location of foreign R\&D activity

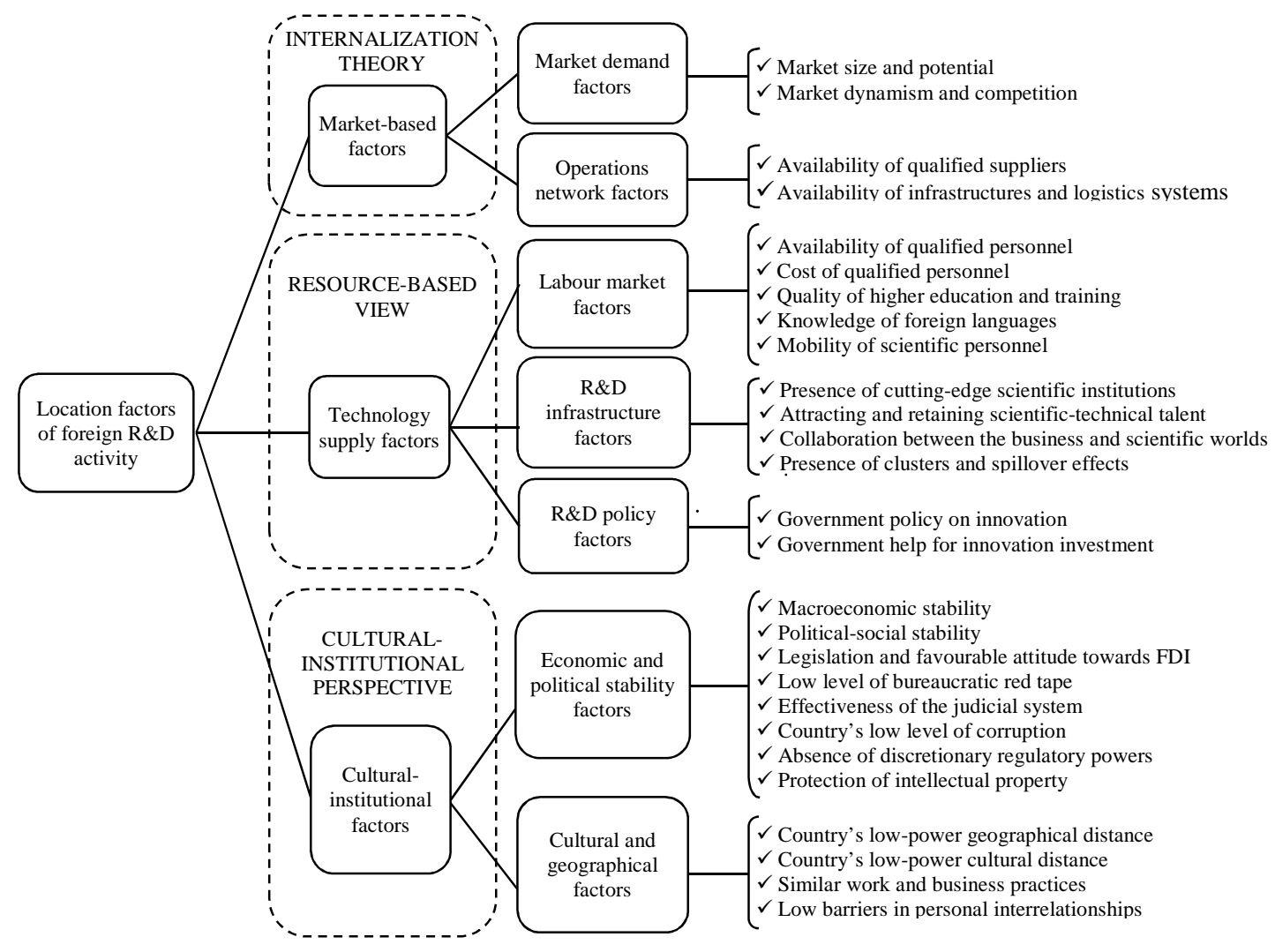

\section{Methodology}

For our qualitative analysis we used the case study method, which has demonstrated its suitability for investigating situations within their real context where the aim is to find out the 'how' and the 'why' (Yin 1990). Specifically, by combining insights from different theoretical perspectives in order to propose a novel and more convincing explanation, and being sensitive to the contexts of individual countries, our approach falls between natural experiment and contextual explanation (Welch et al. 2011).

To choose the cases for analysis we used criteria of theoretical sampling and theoretical saturation, carrying out the selection according to their significance rather than to their representativeness (Eisenhardt 1989). Specifically, we selected eight highprofile Spanish subsidiaries of global MNCs, members of the I+E Innovation Spain Foundation: Alstom, ArcelorMittal, Ericsson, Hero, Hewlett Packard, Sony, 
ThyssenKrupp Elevator and Vodafone (see table 1). The views of these Spanish subsidiaries are particularly relevant, for two reasons. First, they belong to MNCs which have a strong commitment to innovation and have $R \& D$ centres spread across the world, some of them in BRIC countries. Second, they have successfully consolidated R\&D centres of excellence in Spain, generating innovative applications for the entire corporation. Thus, they have achieved a competence-creating mandate while competing with the emergence of the BRIC countries. Moreover, managers of these subsidiaries are well aware of the R\&D conditions in the BRIC economies, since their familiarity with the strengths and weaknesses of their rival locations helps them to face the threat of delocalization. Overall, their experience competing with the BRIC countries makes them ideal informants for the objectives of the current study (Piekkari and Welch 2006).

The primary information was gathered in June 2012 from several semistructured interviews lasting approximately two hours. Face-to-face joint meetings were held by the research team with directors and senior management of the foreign subsidiary involved in innovation - generally the managing directors, the heads of R\&D and others responsible for this function in the subsidiary (see table 1).

We used a research protocol in order to guarantee the reliability of the casestudy analysis (Yin 1990). Interviewees were asked, first, to give full descriptions of their strategies in the area of innovation. Second, they were asked to assess location factors frequently used in previous empirical studies, classified beforehand in seven groups stemming from the literature review (figure 1). Third, interviewees discussed the factors that could be considered as strengths or weaknesses in Spain for attracting R\&D investment compared with the BRICs.

Once all the data were collected, the information was processed and irrelevant content was filtered out. All the interviews were recorded, transcribed and coded in 
order to structure the data and to make sure that the information could be reassessed if inconsistencies were found. As a result, we were able to discuss the diverse views and set up a first preliminary hierarchy group of location factors, which we then sent back to the interviewees so that they could reconsider their earlier judgments if necessary. Common and conflicting viewpoints were identified and gradually resolved through mail exchange and phone calls in order to reach a final consensus.

In addition, to strengthen the reliability of the study, the results were complemented by information triangulation based on documents produced by the MNCs and from other official secondary sources (such as the OECD; World Bank; World Economic Forum and the Global Innovation Index). Finally, two external experts from the FECYT (Spanish Foundation for Science and Technology) read the results independently to form their own judgements and to corroborate the final interpretations. 
Table 1. Case study characteristics

SPANISH SUBSIDIARY

\begin{tabular}{|c|c|c|c|c|c|c|c|c|c|c|c|}
\hline \multirow[b]{3}{*}{ CORPORATION } & \multicolumn{11}{|c|}{ SPANISH SUBSIDIARY } \\
\hline & \multirow[b]{2}{*}{ Subsidiary R\&D activity } & \multirow{2}{*}{$\begin{array}{c}2012 \\
\text { Turnover } \\
(€ \text { million })\end{array}$} & \multirow{2}{*}{$\begin{array}{l}2012 \\
\text { No. } \\
\text { Staff }\end{array}$} & \multirow{2}{*}{$\begin{array}{c}2012 \\
\mathrm{R} \& \mathrm{D} \\
(€ \text { million})\end{array}$} & \multicolumn{4}{|c|}{ R\&D Distribution } & \multirow{2}{*}{$\begin{array}{c}2012 \\
-\mathrm{R} \& \mathrm{D} \\
\text { centres }\end{array}$} & \multirow{2}{*}{$\begin{array}{l}2012 \\
\text { No. R\&D } \\
\text { Staff }\end{array}$} & \multirow[b]{2}{*}{ Interviewees at the Spanish Subsidiary } \\
\hline & & & & & $\begin{array}{c}\% \\
\mathrm{BR} \\
\end{array}$ & $\begin{array}{c}\% \\
\mathrm{AR}\end{array}$ & $\begin{array}{c}\% \\
\text { Product }\end{array}$ & $\begin{array}{c}\% \\
\text { Process }\end{array}$ & & & \\
\hline $\begin{array}{l}\text { Alstom } \\
\text { French MNC in rail } \\
\text { transport } \\
\text { infrastructure, power } \\
\text { generation and } \\
\text { transmission }\end{array}$ & $\begin{array}{l}\text { The headquarters of the Wind division** and the world } \\
\text { R\&D centre are in Barcelona. They design wind } \\
\text { turbines for worldwide use. Alstom has two innovation } \\
\text { centres in Spain (the Transport and Hydro divisions) } \\
\text { which carry out product adaptation, search for } \\
\text { environmental solutions and create new products for the } \\
\text { whole group. }\end{array}$ & $1,193.82$ & 4,025 & 25 & $\begin{array}{l}-- \\
\end{array}$ & $20 \%$ & $50 \%$ & $30 \%$ & $\begin{array}{l}1(+3) \\
\text { R\&D } \\
\text { centre } \\
+ \text { tech } \\
\text { innov. } \\
\text { centre }\end{array}$ & $-* *$ & $\begin{array}{l}\bullet \text { R\&D Engineer } \\
\text { - Executive Director }\end{array}$ \\
\hline $\begin{array}{c}\text { ArcelorMittal } \\
\text { Steel group with head } \\
\text { office in Luxembourg }\end{array}$ & $\begin{array}{l}\text { Design and development of new production processes } \\
\text { for the whole MNC. Its R\&D centres improve } \\
\text { steelmaking processes and conduct research on } \\
\text { products for the construction industry. }\end{array}$ & $2,400.37$ & 6,030 & 7.33 & $10 \%$ & $50 \%$ & -- & $40 \%$ & 2 & 74 & $\begin{array}{l}\bullet \text { Director of Global R\&D Asturias Centre and } \\
\text { Global R\&D Spain }\end{array}$ \\
\hline \begin{tabular}{c|} 
Ericsson \\
Swedish supplier of \\
telecom equipment \\
and multimedia \\
solutions \\
\end{tabular} & $\begin{array}{l}\text { Development of new products or components. Ericsson } \\
\text { R\&D Madrid interacts proactively and transfers new } \\
\text { developments of products and processes to the rest of } \\
\text { the MNC. }\end{array}$ & 778.02 & 2,161 & 70 & $10 \%$ & $80 \%$ & $10 \%$ & -- & 1 & 550 & - Manager of Policy \& DPI Product Management \\
\hline $\begin{array}{l}\text { HewlettPackard } \\
\text { US company } \\
\text { providing IT } \\
\text { solutions }\end{array}$ & $\begin{array}{l}\text { HP's R\&D centre in Barcelona has a world mandate for } \\
\text { large format printing and the European mandate for } \\
\text { deskjets. It develops new products for the MNC, } \\
\text { transferring knowledge and results from the subsidiary } \\
\text { to the group. }\end{array}$ & $1,215.89$ & 2,770 & 60 & $10 \%$ & $20 \%$ & $60 \%$ & $10 \%$ & 1 & $\begin{array}{c}600 \\
\text { (direct \& } \\
\text { indirect) }\end{array}$ & $\begin{array}{l}- \text { R\&D Director } \\
- \text { R\&D Planning Manager Large Format Division } \\
\bullet \text { Vice President and General Manager of Large } \\
\text { Format Division } \\
\text { - Government Affairs Manager }\end{array}$ \\
\hline $\begin{array}{c}\text { Sony } \\
\text { Japanese MNC } \\
\text { producing consumer } \\
\text { electronics }\end{array}$ & $\begin{array}{l}\text { Development of new TV products for all Europe } \\
\text { (electrical engineering, tuning, electrical signalling). It } \\
\text { adapts products to the requirements of the European } \\
\text { market. }\end{array}$ & $158,86^{*}$ & $37^{*}$ & 4 & -- & $70 \%$ & $15 \%$ & $15 \%$ & 1 & 90 & $\begin{array}{l}\text { - General Manager, Sony Iberia } \\
\text { - Finance and Operations Director, Sony Iberia }\end{array}$ \\
\hline $\begin{array}{l}\text { ThyssenKrupp } \\
\text { Elevator } \\
\text { German corporation } \\
\text { in the lift sector }\end{array}$ & $\begin{array}{l}\text { Development of new products or components for all } \\
\text { group. The world HQ for horizontal transport is in } \\
\text { Spain. R\&D centre focused on lifts and lifting } \\
\text { equipment. }\end{array}$ & 379,93 & 3.068 & 5.7 & $30 \%$ & $40 \%$ & $15 \%$ & $15 \%$ & 2 & 90 & $\begin{array}{l}\text { - Managing Director, ThyssenKrupp Elevator } \\
\text { Innovation Center } \\
\text { - Business Development Manager }\end{array}$ \\
\hline \begin{tabular}{c|} 
Vodafone \\
UK \\
telecommunications \\
company
\end{tabular} & $\begin{array}{l}\text { Product adaptation to the preferences and needs of } \\
\text { customers in different countries and adaptation of } \\
\text { processes to the resources of the subsidiary. }\end{array}$ & $4,810.73$ & 4,216 & 3 & -- & $10 \%$ & $80 \%$ & $10 \%$ & 1 & 26 & $\begin{array}{l}\text { - Directors of Press Office and External Relations } \\
\text { - R\&D Director of Vodafone Spain's excellence } \\
\text { centres } \\
\text { - Executive Chairman and CEO }\end{array}$ \\
\hline
\end{tabular}

Notes: \%BR=Percentage of $R \& D$ allocated to basic research; $\% A R=$ Percentage of $R \& D$ allocated to applied research

$\%$ Product $=$ Percentage of $R \& D$ allocated to experimental product development; \%Process $=$ Percentage of $R \& D$ allocated to experimental process development

* Data for Sony Computer Entertainment España; **Until 2015, Alstom comprised three business units: Transport, Grid and Power (Thermal, Wind and Hydro divisions).

Source: The companies themselves and the SABI database 


\section{Location factors of international $R \& D$ activity. Spain versus BRIC countries}

The case studies indicate that the influence of environmental factors on FDI decisions varies substantially. Here, we present the seven factors ordered according to their importance.

\subsection{Factors related to $R \& D$ policy}

Not all the groups of $\mathrm{R} \& \mathrm{D}$ location factors resulting from the theoretical framework have the same level of influence on the destination of FDI (see figure 2). Government policy on innovation has the greatest bearing on MNCs’ R\&D decisions since it involves the access to financial resources. BRIC countries significantly outperform Spain with regard to national-specific strategic plans designed to promote certain R\&D fields of political interest. Indeed, they regularly launch multiple custom-made action plans that provide public funding for developing R\&D in priority industries (e.g., telecommunications or energy).

Furthermore, BRICs also provide better public general funding (in the form of direct subsidies and tax incentives and deductions), which is something that MNCs value highly. The companies interviewed often use direct funding for innovation provided by the Spanish government. However, the cuts ${ }^{1}$ in this type of incentive over the last few years have eroded the competitive advantage of Spanish subsidiaries, especially in comparison with subsidiaries in emerging economies, where public funding has remained stable or has even increased. Although Spain has made major

\footnotetext{
${ }^{1}$ There has been significant disinvestment in Spanish public R\&D budgets for R\&D since the financial crisis. Public R\&D funding reached its highest level in 2009 (€8,700m) but by 2013 had fallen by $39 \%$, returning to the levels of 2005-2006 (RIO, 2015).
} 
investments in terms of its expenditure on R\&D (amounting to 1.3\% of GDP in 2015, according to the OECD), it lags far behind the European 2020 objective of 3\%. Russia (1.1\%), Brazil (1.2\%) and India (0.8\%) were behind Spain, while China (1.9\%) was ahead.

Furthermore, the MNCs interviewed considered that the Spanish tax system should be redefined now that the BRIC countries offer very tempting tax incentives in order to attract R\&D activities. Brazil, for example, allows "super deductions" equal to $160 \%$ of the total R\&D expenditure and an extra $20 \%$ deduction for the qualifying costs incurred in developing a patent. China also offers deductions of $150 \%$ of total R\&D expenditure. For its part, Russia does not tax intellectual property transactions, and exempts companies from paying tax in special economic zones (SEZs). India has the highest taxation benefits for R\&D activities (up to 200\%) for in-house R\&D expenditure, including capital expenditure (Deloitte, 2014).

In Spain, in contrast, taxation on R\&D presents two main disincentives. First, there is a time limit for applying and submitting outstanding tax deductions; this means that they cannot be accumulated and that many deductions cannot be applied. Second, obtaining tax deductions is conditional upon the subsidiary's commercial success and profits in the Spanish market, rather than upon the results of the actual research activity carried out in the R\&D unit.

\subsection{Factors related to economic and political stability}

As far as the institutional environment is concerned, political and economic stability and the country's risk indices were the most relevant aspects. For Sony, 'the unfavourable economic situation, with a very high-risk premium, does not help to attract R\&D. In times of change, high volatility and international uncertainty, MNCs do not opt for inflexible countries with high barriers from the start'. During downturns, the rigid 
regulation regarding setting up and operating in a particular country (and possibly divesting from it) is seen as a significant hurdle. This idea was also stressed by the Ericsson manager who stated that 'macroeconomic instability makes it more difficult to carry out a long-term strategy of industry creation and local commitment'.

Despite its international nature, the financial crisis has hit intermediate countries like Spain harder than others ${ }^{2}$. For ThyssenKrupp, 'macroeconomic instability in Spain reduces public funding and worsens the country's image abroad. If it continues over time, it could lead to the relocation of the MNC's R\&D centres in Spain to other countries such as Germany, for company policy reasons, or China, for market reasons.'

However, in other aspects less dependent on the economic situation but which also give a country stability - such as the level of bureaucracy in government, the effectiveness of the judicial system, the protection of intellectual property and an attitude and legislation favourable towards FDI - Spain has a clear competitive advantage over the emerging economies. For HP, 'struggling with red tape in China is complicated, but in India it's infuriating'. And according to Hero, 'Brazil is extremely protectionist as far as legal security is concerned because it has a huge, insecure legal system, which complicates things enormously; neither is there very much security in Russia or China when it comes to business activities'. As regards the protection of intellectual property, intermediate countries have a competitive advantage over emerging countries, with China faring particularly badly. This is due firstly to the high risk of opportunistic behaviour (the risk of imitation and copying) in emerging countries, and secondly to ineffective law enforcement and a lack of a legal system that penalizes this behaviour. According to Vodafone, 'the protection of intellectual property

\footnotetext{
${ }^{2}$ For example, according to the OECD, real GDP annual growth in Spain was $-0.62 \%$ in 2011, compared with $4.26 \%$ in Russia and $9.30 \%$ in China.
} 
in Spain is considered a strong point'. Of the approximately 30 patents that Vodafone's subsidiary registers annually, all are triadic: first they are registered in Spain, and then they are passed on to the MNC which registers them worldwide.

Discretionary regulatory powers and corruption also reduce the competitiveness of emerging economies. While in Spain expropriations, nationalizations or a sudden rejection of the obligations taken on by the government long before no longer jeopardize political stability, in the BRICs such practices remain a very real threat today. Consequently, the immaturity of political and economic institutions in emerging countries makes it less likely that foreign MNCs will invest in R\&D. This places intermediate countries such as Spain in a more advantageous position.

\subsection{Factors related to the labour market}

The third most important aspect influencing the location of international R\&D activities is the labour market. In this respect, Spain compares well with the BRIC countries, especially as regards the availability of qualified personnel and the quality of its higher education $^{3}$. However, according to Alstom, 'although there are some excellent universities in Spain that turn out highly competitive scientists on an international level, they still need to take action to train people in entrepreneurial initiative'.

The learning of foreign languages has traditionally been a weak point in Spain, but the situation has improved over time. According to Hero, 'the level of English among Spanish research staff isn't as high as it could be, but they can certainly be said to get by'.

\footnotetext{
${ }^{3}$ According to the OECD, the number of full-time researchers per thousand employees rose by $52.67 \%$ between 2000 and 2012, but in emerging countries the rate was considerably higher, reaching $90.63 \%$ in China.
} 
Another crucial subject is the cost of scientific personnel. In this respect Spain is perceived by the managers interviewed as being less competitive than the emerging countries, although according to Hero 'MNCs do not decide on the location of R\&D on the basis of costs alone, but also on expected results, and in this respect Spain offers a better quality-to-price ratio than you would find in the BRICs'. HP agrees that 'to equal the return on one Spanish researcher, you would need to consider the work of more than one Chinese or Indian researcher'.

The lack of loyalty or commitment among company employees, which generates a high turnover of research staff, is another key factor that reduces the competitiveness of emerging countries. This high turnover lowers performance and raises employee costs because of the associated expense of replacing staff. In that sense, in 2011the US multinational HP moved part of its R\&D, previously located in Brazil and India, to a new base in Leon (Spain), establishing a new Software Development Centre with 300 highly qualified staff and 10 million euros of investment. HP relocate its R\&D because its activities in these countries were not only affected by geographical, linguistic and cultural barriers, which made communication and coordination difficult, but also by problems involving the high turnover of research staff and salary inflation. According to HP, 'sometimes in these emerging countries you not only need to pay the engineer or researcher you employ, but also the substitute who is "on the bench" waiting to find out if the regular player will decide to leave halfway through the project'. All this leads to higher salary costs that may wipe out any difference in payroll costs, especially as regards qualified personnel. Moreover, ArcelorMittal stated that 'a recently qualified engineer in India has a slightly lower salary than a recently qualified engineer in Spain, but the costs equal out when other additional expenses such as travel allowances and visas, etc. are taken into account.' 


\subsection{Factors related to $R \& D$ infrastructure}

In fourth place, the country's R\&D infrastructure enables MNCs to access new technological resources, capabilities, and the networks of potential partners. For Vodafone, 'the search for talent and closer relations between the scientific and business worlds is fundamental for MNC innovation processes. Countries should work towards building a network of innovation capable of using and retaining any talent that may appear'.

Spain still holds competitive advantages over the emerging economies in terms of the availability of scientific institutions and the ability to attract scientific talent, but the BRIC countries are gradually catching up in this respect ${ }^{4}$. According to Hero, 'Spain's level of science is good although more investment needs to be made'.

However, Spain lags behind the BRICs with regard to the presence of technology clusters, where Asian countries are clearly in the lead. Bangalore in India is home to a series of highly prestigious schools and research centres. On the east coast of China there are also numerous clusters, such as those for electronic products in Dongguan or transport equipment in Shandong. However, according to ThyssenKrupp, 'there is a high degree of concentration industry in China, but they can't be considered true technology clusters because they're not really well organized'.

The gap between the scientific-academic world and the business world is another key factor that could be improved in Spain. For Sony, 'there is significant separation because, despite the high potential of Spanish research centres and the resources invested, their objectives are very different and quite detached from those of

\footnotetext{
${ }^{4}$ Between 2004 and 2014, Spain ranked ninth out of 150 countries in terms of the number of scientific articles published, below China (second position) but above India (10th), Brazil (14th) and Russia (15th) (Essential Science Indicators. Thomson Scientific).
} 
the business system'. Bridges therefore need to be built to improve collaboration and knowledge transfer between the two systems. In this respect, the MNCs interviewed proposed the compilation of a directory containing up-to-date information on groups and lines of research in universities, technology centres and public institutions in Spain in order to collaborate on specific problems or to develop joint research projects.

\subsection{Factors related to operations networks}

The presence of operations networks is the fifth factor. Although these networks are more closely linked to international location decisions involving production activity in order to keep transaction costs down, they also have an effect on project allocation, especially when related to development activities.

According to Hero, 'infrastructures and suppliers need to be close, reliable and responsible - otherwise it's impossible to innovate'. HP also believes that 'the best thing would be to find a country with suppliers both competitive in production costs and with the required capabilities to carry out R\&D activities'.

Spain is considered to have a competitive advantage over India as regards both the availability of qualified suppliers and infrastructures and logistics systems, but not over China. The need for reliable operations networks is of crucial importance for Hero: 'the emerging countries with the highest levels of infrastructure are China, Russia and Brazil. India lags behind, apart from Bangalore... in fact infrastructure levels should be analysed by area rather than by actual country'. Regarding Chinese suppliers, ThyssenKrupp commented that 'it's more about quantity than quality, and therefore you need a certain critical mass to be able to buy in China'.

\subsection{Factors related to a country's culture and geography}

Next we find factors related to geographical and cultural differences. ArcelorMittal, 
which has a R\&D centre in a small city in the north of Spain (Asturias), says that 'interconnectivity is very important, especially with customers. The cutting of flight routes from secondary airports is a big handicap because it takes more time to do the same journey'. There are also difficulties with visas and red tape that need to be dealt with before being able to travel, especially for employees of subsidiaries in emerging countries. In this respect Sony points out that 'Brazilian, Chinese and Indian researchers always have problems with visas before they can come for short three-month stays in our country'.

As for the cultural differences between countries, MNCs believe that China is the country that presents the biggest problems for interaction. According to Hero, 'it's easy to make yourself understood with a Brazilian or an Indian, but it's very difficult with a Chinese. Their way of thinking, their personal relationships, the language, all this make them very different'. For ThyssenKrupp, 'due to the low cost per hour, the way work is carried out in China is very different from the way we work in Europe; whereas here we analyse an idea, develop it and test it only when we are very clear about it, in China they use trial and error as a normal procedure. This involves a lot of protocol problems'. Furthermore, according to HP, 'it is difficult to find supervisors in China because their cultural vision of hierarchical structures makes decision making difficult. Only staff educated outside China manage to overcome this problem'.

\subsection{Factors related to market demand}

Market demand in the host country ranks last among the factors analysed, but it also has an influence on R\&D location. MNCs may transfer technology to the host country in order to exploit the resources and capabilities that confer competitive advantage worldwide. According to Hero, 'when a market gains weight it justifies more investment in $R \& D$ because a large volume of business in the country means that 
development activities are also carried out, especially those involving adaptation to that market'. Spain has a lower level of market demand than the BRICs. This is to be expected, bearing in mind the high growth forecast for these emerging economies.

Figure 2 presents a summary of the results, comparing Spain versus BRIC countries.

Figure 2. Comparison of R\&D location factors. Spain versus BRIC countries

\begin{tabular}{|c|c|c|c|}
\hline $\begin{array}{l}\text { Group of factors (from most } \\
\text { to least important) }\end{array}$ & Spain's strengths & Comparable & BRICs' strengths \\
\hline 1. R\&D policy & & & $\begin{array}{l}\text { - Government policy on innovation } \\
\text { - Government help for innovation } \\
\text { investment }\end{array}$ \\
\hline $\begin{array}{l}\text { 2. Economic and } \\
\text { political stability }\end{array}$ & $\begin{array}{l}\text { - Political-social stability } \\
\text { - Low level of bureaucratic red tape } \\
\text { - Effectiveness of the judicial system } \\
\text { - Protection of intellectual property } \\
\text { - Absence of discretionary regulatory } \\
\text { powers } \\
\text { - Country's low level of corruption }\end{array}$ & $\begin{array}{l}\text { - Legislation and favourable } \\
\text { attitude towards FDI }\end{array}$ & - Macroeconomic stability \\
\hline 3. Labour market & $\begin{array}{l}\text { - Quality of higher education \& } \\
\text { training } \\
\text { - Mobility of scientific personnel }\end{array}$ & $\begin{array}{l}\text { - Availability of qualified } \\
\text { personnel } \\
\text { - Knowledge of foreign languages }\end{array}$ & - Cost of qualified personnel \\
\hline 4. $R \& D$ infrastructure & & $\begin{array}{l}\text { - Presence of cutting-edge } \\
\text { scientific institutions } \\
\text { - Attracting and retaining } \\
\text { scientific-technical talent }\end{array}$ & $\begin{array}{l}\text { - Collaboration between the } \\
\text { business and scientific worlds } \\
\text { - Presence of clusters and spillover } \\
\text { effects }\end{array}$ \\
\hline 5. Operations network & $\begin{array}{l}\text { - Availability of qualified suppliers } \\
\text { - Availability of infrastructures and } \\
\text { logistics systems }\end{array}$ & & \\
\hline $\begin{array}{l}\text { 6. Cultural and } \\
\text { geographical factors }\end{array}$ & $\begin{array}{l}\text { - Country's low-power geographical } \\
\text { distance } \\
\text { - Country's low-power cultural } \\
\text { distance } \\
\text { - Low barriers in personal } \\
\text { interrelationships } \\
\text { - Similar work and business practices }\end{array}$ & & \\
\hline 7. Market demand & & & $\begin{array}{l}\text { - Market size and potential } \\
\text { - Market dynamism and } \\
\text { competition }\end{array}$ \\
\hline
\end{tabular}

* The shaded areas represent the country's main strengths

\section{Discussion and conclusions}

The appearance of emerging countries on the world $R \& D$ scene is creating a new pattern of geographical distribution for international R\&D. Our results suggest that the emerging economies have caught up with Spain in factors involving demand and, in particular, in factors connected with R\&D support policies. The policies adopted by 
some emerging economies are yielding impressive results and these countries today match Spain in terms of the availability of scientific talent at competitive cost, and of the quality of their universities and research centres. The recent investments in these areas made by these countries have helped to train a large body of scientific personnel with the skills needed to participate in the development of knowledge-intensive research projects. However, the instability of their institutions and the uncertainty in the business environment significantly undermine the capacity of their supply-side factors to attract FDI in R\&D.

These findings have some implications for theory. The MNCs' R\&D foreign expansion into emerging economies has gone beyond the original rationale provided by internalization theory. MNCs not only internationalize their R\&D activity to control the transfer of knowledge to subsidiaries, giving them technical support to adapt products to local needs, but they are also establishing an increasing number of R\&D labs in order to tap into specific bodies of local knowledge (Kuemmerle 1999). This development is neatly explained by the resource-based view, since MNCs' FDI in emerging economies seems to place a greater emphasis on the availability of qualified labour and government support for innovation. However, these factors are primarily facilitators of the location of development activities (Kuemmerle 1999; Ambos and Ambos 2011). Moreover, the emerging economies' deliberate enactment of policy measures to promote high research-intensive activities obliges MNCs to pay greater attention to their supply-side potential. The cultural-institutional perspective completes this balancing, inasmuch as it provides the environment for developing these two groups of factors (especially technology-supply factors). Cultural-institutional factors do not attract foreign investment in R\&D on their own: they matter more to MNCs when operating in emerging economies than in developed countries, where the legal framework is more 
robust. This highlights the crucial interconnection of the resource-based view and cultural-institutional perspective in order to better understand the distribution of MNCs' research-intensive activities among countries.

Figure 3 plots the theoretical framework drawn from the literature review and the empirical results on an axis of coordinates. When we combine the technologysupply criterion with the notion of cultural-institutional proximity, the attractiveness of countries may diverge, primarily in two ways. First, we find countries which are weak in the supply side factors but are institutionally stable: for instance, intermediate countries whose moderate $R \& D$ capacity is offset by the soundness of their institutions (position I in figure 3). Second, we find countries whose technology-supply factors may be high to the detriment of their cultural-institutional factors: for instance, emerging economies whose institutional and political instability (along with cultural barriers) prevents them from fulfilling their technology-supply potential (position $\mathrm{E}$ in figure 3).

Figure 3. Countries' attractiveness for FDI in R\&D

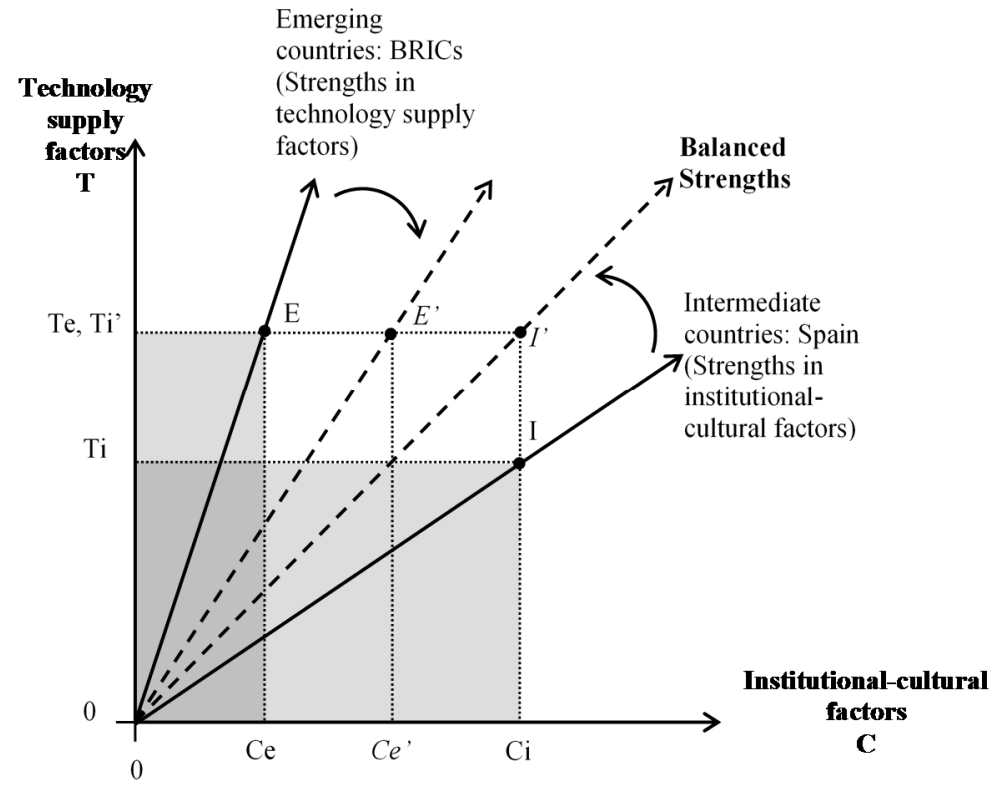

As shown by the dashed arrows, as soon as these emerging economies resolve the problems in their institutional framework, their attractiveness for R\&D shifts from $\mathrm{E}$ to 
E' and the shaded area that defines their attractiveness for R\&D will be the same as that of the intermediate countries. Therefore, they may be able to overtake intermediate countries in the competition for international $R \& D$. The challenge for intermediate countries like Spain consists of strengthening whatever makes their technology supply distinctive before they are overtaken by the emerging economies. In this process, they move their position up from I to I', towards a greater balance between supply- and institutional-side factors.

Consequently, the framework suggests how countries might strengthen their position in the race to capture international R\&D. Particularly, to retain and attract FDI in $\mathrm{R} \& \mathrm{D}$, intermediate countries will need to introduce various cross-sectional measures involving all players and affecting different areas of national policy. These measures should be applied in three main areas. Firstly, more support needs to be given to the development of research centres and top-class universities that can become international benchmarks. Positive measures in this area would include the establishment of a good grants system for training young research staff, better practical training for researchers to equip them for management and entrepreneurship, and programmes aimed at attracting and retaining scientific talent (i.e., halting the brain drain). Secondly, the gap between the scientific and business worlds needs to be narrowed, by coordinating objectives and building bridges of dialogue in order to improve knowledge transfer. Action in this area would include the construction of a road map with up-to-date information identifying groups and lines of research. Thirdly, new formulas should be designed for encouraging inter-company collaboration. R\&D alliances between local and non-local companies could serve as bridges for transferring knowledge.

These policy recommendations should, however, be treated with a certain amount of caution. Not all forms of FDI are equal, and the same is true for intermediate 
countries. This study has focused on eight subsidiaries located in Spain with a very narrow profile, i.e., subsidiaries with competence-creating roles. The conclusions offered here are based on the perceptions of the managers of subsidiaries of this kind; however, because they might be biased by these managers' present positions, the analysis may need to be extended in future. What is more, in the simple model used here, technology-supply and cultural-institutional determinants are homogeneously defined and scaled as factor-weighted averages of attracting determinants. However, each determinant has a different capacity for attracting MNCs' FDI in R\&D. Moreover, neither technology-supply nor cultural-institutional factors alone can fully explain the MNC's destination for R\&D FDI; other factors such as market-based factors, supply chain characteristics, and most notably, the firm's motivations for investing in R\&D may also influence the decision. Future research should extend the analysis to include other motivations, since a shift in the motives involves a change in the drivers of local R\&D (Cantwell and Mudambi 2005).

All in all, our graphic model, while intuitive, is affected by discretional simplification and boundary decisions which are somewhat artificial but nevertheless necessary for furthering our understanding of the area. Future research should refine these assumptions against competing hypotheses, in order to strengthen the conclusions presented here.

\section{References}

Achcaoucaou, F., P. Miravitlles, and F. León-Darder. 2014. 'Knowledge sharing and subsidiary R\&D mandate development: A matter of dual embeddedness.' International Business Review 23 (1): 76-90.

Ambos, B., and T. C. Ambos. 2011. 'Meeting the challenge of offshoring R\&D: an examination of firm- and location-specific factors.' $R \& D$ Management 41 (2): 107-119. 
Buckley, P.J., and M. Casson. 1976. The future of the multinational enterprise. New York: Holmes \& Meier.

Buckley, P.J., and N. Hashai, 2014. 'The role of technological catch up and domestic market growth in the genesis of emerging country based multinationals." Research Policy 43: 423-437.

Cantwell, J., and R. Mudambi. 2005. 'MNE competence-creating subsidiary mandates.' Strategic Management Journal 26 (12): 1109-1128.

Castellani, D., A. Jimenez, and A. Zanfei. 2013. 'How remote are R\&D labs? Distance factors and international innovative activities.' Journal of International Business Studies 44 (7): 649-675.

Chidlow, A., C. Holmström-Lind, U. Holm, and S. Tallman. 2015. "Do I stay or do I go? Sub-national drivers for post-entry subsidiary development." International Business Review 24(2): 266-275.

Dachs, B., F. Kampik, T. Scherngell, G. Zahradnik, D. Hanzl-Weiss, G. Hunya, N. Foster, S. Leitner, R. Stehrer, and W. Urban. 2012. Internationalisation of Business Investments in $R \& D$ and Analysis of Their Economic Impact. Luxembourg: European Commission.

de Woskin, K. J. 2008. 'China: Key issues for business'. In China into the future: Making sense of the world's most dynamic economy, edited by W. J. Hoffmann, and M. J. Enright, 61-106. Singapore: John Wiley.

Deloitte. 2014. 2014 Global Survey of $R \& D$ Tax Incentives. Deloitte. Available online: http://www2.deloitte.com/content/dam/Deloitte/global/Documents/Tax/dttl-taxglobal-rd-survey-aug-2014.pdf (Accessed 5 May 2016).

Demirbag, M., and K. W. Glaister. 2010. 'Factors Determining Offshore Location Choice for R\&D Projects: A Comparative Study of Developed and Emerging Regions.' Journal of Management Studies 47 (8): 1534-1560.

Doh, J. P., G. K. Jones, R. Mudambi, and H. Teegen. 2005. 'Foreign research and development and host country environments: An empirical examination of U.S. International R\&D.' Management International Review 45(2): 121-154.

Dunning, J.H. 1980. 'Toward an eclectic theory of international production: some empirical tests.' Journal of International Business Studies 11 (2): 9-31.

Eisenhardt K.M. 1989. 'Building Theories from Case Study Research.' Academy of Management Review 14 (4): 532-550. 
European Commission. 2012. ERAWATCH Annual Country Reports. Available online: http://erawatch.jrc.ec.europa.eu/ (Accessed 21 December 2013).

Evangelista, R., S. Iammarino, V. Mastrostefano and A. Silvani. 2015. "Looking for Regional Systems of Innovation: Evidence from the Italian Innovation Survey." Regional Studies 36 (3): 173-186.

Filipetti, A., and Peyrarche, A. 2011. "The patterns of technological capabilities of countries: A dual approach using composite indicators and data envelopment analysis." World Development 39 (7): 1108-1121.

Flores, R.G., and R.V. Aguilera. 2007 'Globalization and location choice: an analysis of US multinational firms in 1980 and 2000.' Journal of International Business Studies 38 (7): 1187-1210.

GII 2015. The Global Innovation Index. Available at: https://www.globalinnovationindex.org (accessed 21 December 2015)

Guimón, J. 2009. 'Government strategies to attract R\&D-intensive FDI.' The Journal of Technology Transfer 34 (4): 364-379.

Kostova, T., and S. Zaheer. 1999. "Organizational Legitimacy Under Conditions of Complexity: The Case of the Multinational Enterprise." Academy of Management Review 24 (1): 164-81.

Kuemmerle, W. 1999. 'The Drivers of FDI into Research and Development: An Empirical Investigation.' Journal of International Business Studies 30 (1): 1-24.

Miravitlles, P., L. Guitart-Tarrés, F. Achcaoucaou, and A. Núñez-Carballosa. 2013. 'The role of the environment in the location of $\mathrm{R} \& \mathrm{D}$ and innovation activities in subsidiaries of foreign multinationals.' Innovation: Management, Policy \& Practice 15 (2): 170-183.

Piekkari, R., and C. Welch. 2006. "Reflections on using qualitative research methods." The Finnish journal of Business Economics (LTA) 04/06, 565-574. Available online: http://lta.hse.fi/2006/4/lta_2006_04_a7.pdf (Accessed 19 April 2016).

Prahalad, C.K., and G. Hamel. 1990. 'The core competence of the corporation.' Harvard Business Review 68: 79-91.

RIO. 2015 Research and Innovation Observatory. European Commission. RIO country report: Spain. Available online: https://rio.jrc.ec.europa.eu (Accessed 21 December 2015). 
Sachwald, F. 2008. 'Location choices within global innovation networks: the case of Europe.' Journal of Technology Transfer 33 (4): 364-378.

Siedschlag, I., D. Smith, C. Turcu, and X. Zhang. 2009. 'What Determines the Attractiveness of the European Union to the Location of R\&D Multinational Firms?' Papers WP306, Economic and Social Research Institute (ESRI).

Thursby, J., and M. Thursby. 2006. Here or there? A survey on the factors in multinational $R \& D$ location. Washington: National Academies Press.

UNCTAD. 2015. World investment report 2015. Geneva: United Nations.

Voelker, R., and R. Stead. 1999. 'New technologies and international locational choice for research and development units: Evidence from Europe'. Technology Analysis \& Strategic Management 11(2): 199-209.

Welch, C., Piekkari, R., Plakoyiannaki, E., and E. Paavilainen-Mäntymäki. 2011. 'Theorising from case studies: Towards a pluralist future for international business research.' Journal of International Business Studies 42 (5): 740-762.

World Economic Forum. 2015. The Global Competitiveness Report. Geneva: World Economic Forum.

Yin, R.K. 1990. Case study research: Design and methods. Newbury Park, Calif.: Sage. 